\title{
A Pragmatic Analysis of Victory and Inaugural Speeches of President Umaru Musa Yar'Adua
}

\author{
Omoniyi Moses Ayeomoni \\ Department of English, Obafemi Awolowo University, Ile-Ife, Osun State, Nigeria \\ Email: ayestyle@yahoo.com \\ Olajoke Susan Akinkuolere \\ Department of General Studies, Rufus Giwa Polytechnic, Owo, Ondo State, Nigeria \\ Email: Olujoke2126@yahoo.com
}

\begin{abstract}
The study was conducted to identify the speech acts features of President Umaru Yar'Adua's Victory and Inaugural Speeches. Hence, the study focused on the pragmatic functions of locution, illocutionary and perlocutionary acts of the speeches. This was done with a view to determine the global pattern of pragmatic moves of the selected political speeches. The data were drawn from the Victory speech and Inaugural Speech and analyzed following the Speech Act theory of Austin (1962) and Searle (1969). The tabular presentations of the analysis were drawn showing the relative frequencies of the speech acts and percentages. Twenty (20) sentences were obtained from the speeches, from which forty $(40)$ speech acts (direct and indirect illocutionary acts) were obtained. The findings showed that the Overall Relative Frequency Percentages (ORFPs) for the selected speeches of Umaru Musa Yar'Adua were: assertive-60\%, directive-35\%, expressive-15\%, verdictive- $40 \%$, commisive-30\%, and declarative-20\%. These ORFPs results showed that Umaru Musa Yar'Adua relied more on sentences that performed assertive acts than other speech acts. He used the sentences that were vindictive and directive to assert his authority and exercise his power as the President. Sentences that were expressive had the least ORFP; hence, it was observed that the President exploited less of sentences which were meant for indicating the sincerity of his intentions. The Speech Act analysis of the political discourses of Umaru Musa Yar'Adua provided the understanding that political leaders in Nigeria perform various acts through their speeches. These speech acts assist in the understanding and interpretation of the messages in their speeches.
\end{abstract}

Index Terms - President Umaru Yar'Adua, victory and inaugural speech, pragmatics, speech acts, language of politics

\section{INTRODUCTION}

The primary function of language is for the purpose of communication. Man is distinct from animals since he communicates through language. Language serves as the most vital tool in the hands of man. Thus, language is essential in the implementation of successful democratic rule in any country. Taiwo (2009) observes that language is the conveyer belt of power, It moves people to vote, debate or revolt, And it is therefore a central explanation of political stability or polarization.

Language is essential to politicians. Most activities performed by the politicians are done through the avenue created by language. This includes campaign, manifesto, rally, election, inauguration, governance e.t.c. Political speech is becoming a popular concept especially in the area of linguistic research. The concept of political speech could be said to have originated from the rhetorical works of Greek philosophers like Sophist, Socrates, Plato and Aristotle. Aristotle therefore describes it as 'a faculty of observing in any given case the available means of persuasion in reference to whatever subject' (see Agbogun 2011). Rhetoric as the spring for Political speech is defined by Oxford Advanced Learner's Dictionary as 'a speech or writing that is intended to influence people (...); the skill of using language in speech or writing in a special way that influences or incites people'. Hence, the primary purposes of political speeches are to influence, educate, inform, persuade, incite, or entertain people.

The office of the president is the highest in any country, yet the position needs constant touch or link with the people, one of the ways of achieving this is through speech making. The election of President Umaru Musa Yar'Adua made history in Nigeria as he was the first time that a democratically elected president handed over to another democratically elected president. Any democratic government places premium on the people as democracy is popular for being the government of the people, by the people and for the people. Therefore, speech can be seen as a means of establishing and maintaining social relationships, expressing feelings, and selling ideas, policies and programmes in any society.

Several speeches are made to address the people before election; these speeches could also be referred to pre-election special addresses especially at rally and campaign. After the election, speeches are made from time to time as the situation dictates. It is expected that a candidates that wins an election should address the people that have voted him to power, such known as Victory Speech. The Inaugural Speech is usually made on the occasion of official inauguration of 
an elected candidate. It is the point of delivering the Victory and Inaugural Speeches that politician reaffirm their commitment to serve by reiterating the programmes of their party and electioneering campaign promises. No wonder, Denton and Hahn (1986) in Agbogun (2011) posit that the presidency or governorship office has been recognized as a rhetorical institution whose speeches are enlivened by power to persuade and convince the nation or society on the one hand; and provided avenues for familiarizing the audience with the organization and recognisability of the presidency or governorship office on the other hand, as they encapsulate the nation's or state's. The Victory and Inaugural Speeches were the first two speeches presented of Umaru Musa Yar'Adua as the President and Commander in Chief of the Armed Forces of Nigeria in 2007.

\section{A. Language of Politics}

In Nigeria, the English language serves as an alternative to indigenous languages. Opeibi (2009) posits that English serves as the language of wider communication in the socio-political context of the Nigerian nation. It is obvious that the English language is employed in political activities such as campaign, election, speeches, meeting, etc. Language has been a powerful tool in the hands of political leaders; they manipulate the tool to suit their purposes. Since politics is basically about struggling to control power, it is only through language that such could be accomplished, thereby making language a very strong political weapon.

No doubt, the concepts of 'language' and 'politics' are interwoven. Beard (2000) claims that language of politics ... helps us to understand how language is used by those who wish to gain power, those who wish to exercise power and those who wish to keep power (Taiwo 2009). This appears to be in consonance with the claim of Opeibi (2009) that language is a vital process of setting the personality and the programme of the candidates to the public, with the primary aim of gaining their support and mobilizing them to participate in the process of securing and controlling power. It is quite conceivable that politics has become a linguistic issue while language has become a political issue.

The support that citizens have for the politicians will be determined by what they say and how they say it for success to be achieved whether in candidacy, programmes or policies. No wonder, Opeibi (2009) refers to the relationship that exists between language and politics as symbiotic. Language of politics has been widely researched by various scholars. Taiwo (2009) gives a rather insightful perspective of the subject by claiming that:

The study of language of politics has been carried out within the framework of political rhetoric, linguistic stylistics, pragmatics, discourse analysis and critical discourse analysis.

Aspects of political communication include but are not limited to statements made by politicians, writings of politicians, political speeches, election campaign, parliamentary debates and political interviews.

Also, Beard (2000) observes that political campaigns, speeches, written texts, broadcast are meant to inform and instruct voters about issues that are considered to be of great importance. From these submissions, it is crystal clear that speech making is one of the political activities of politicians which are made possible through the channel opened up by language. Opeibi (2009) emphasizes the fact that:

No matter how good a candidate's manifesto is; no matter how superior political thoughts and ideologies of a political party may be, these can only be expressed and further translated into social actions for social change and social continuity through the facilities provided by language.

A political speech serves as a text, as an output and as a process which may be spoken or written (Opeibi 2009). Some scholars have worked on political speeches from different perspectives. Awonuga (1988) worked on the political rhetorics of Obafemi Awolowo and Awonuga (2005) on the stylistic study of 'sustenance of democracy' of Olusegun Obasanjo. Also, Adetunji (2006) explores deixis in Olusegun Obasanjo speeches.

Ayoola (2005) focuses on the critical discourse analysis of a speech by Nigeria's President Olusegun Obasanjo. In this, he is able to demonstrate the relevance of critical discourse analysis for eliciting political meaning in the use of English. Ayeomoni (2005a) investigates the grapho-syntactic analysis of selected political speeches of some Nigerian military heads of State, the likes of General Murtala Muhammed, General Ibrahim Babangida, Major-General Aguiyi Ironsi and General Olusegun Obasanjo.

Ayeomoni (2005b) also investigates the political speeches of past Nigerian military rulers through linguistic-stylistic analysis. Adeyanju (2009) identifies some works that have also been done on political speeches such as; The stylistic study of war speeches of Yakubu Gowon and Emeka Ojukwu (Oha, 1994), discourse tacts in military coup speeches in Nigeria (Adegbija, 1995) and pragmatic and stylistic perspectives: the form and functions of hedges in a presidential media chat programmes hosted by the Nigerian Television Authority (Ayodabo, 2003). In our contribution to the study of language of politics, particularly political speeches, the speech act analysis which basically follows pragmatic approach is employed to do justice to selected speeches of Umaru Musa Yar'Adua.

Adegbija (1999) submits that:

Pragmatics may be seen as the study of language use in particular communicative contexts or situations of necessity, this would take cognizance of the message being communicated or the speech act being performed; the participants involved; their intention, knowledge of the world and the impact of these on their interactions; what they have taken for granted as part of the context (or the presupposition); the deductions they make on the basis of the context; what is implied by what is said or left unsaid; the impact of the non-verbal aspects of interaction on meaning, etc.(cited in Adeyanju, 2009). 
It is against this backdrop that Opeibi (2009) observes that most politicians are unaware of the fact that there is a link between what is said, what is meant, and the action conveyed by what is said. In the study of political speeches, one major theory that has been effective and adequate for analysis is the Speech Act theory.

\section{B. Theoretical Framework}

Pragmatics will serve as the linguistic approach for the research work, since Pragmatics is one of the major fields in linguistic that could unravel meaning in language use. Pragmatics is meant to provide an inroad into the study of President Umaru Musa Yar'Adua's Victory and Inaugural Speeches. The origin of Pragmatics can be traced to the philosophy of language and the American Philosophical School of Pragmatics. The discipline is an offshoot of Discourse Analysis and a sub-discipline in Linguistics. Discourse Analysis studies the organization of language larger than sentence. Thomas (1995) claims that the most common definitions of Pragmatics are 'meaning in use' and 'meaning in context'. This definition emphasizes the fact that Pragmatics as a field of study deals with the use of language in relation to the users and interpreters.

The linguistic framework of any linguistic research serves as the tool for the analysis of data. Hence, the theory of Speech Acts would serve as the spread sheet for the analysis and evaluation of the selected speeches. The choice of Speech Acts theory as the linguistic framework for the President Umaru Musa Yar'Adua's Victory and Inaugural Speeches is premised on the fact that people perform various actions through the use of words and when utterances are made, a particular act is performed; this is called Speech act. The Speech Acts theory is also described as "How to Do Things with Words Theory" since it has its roots in the work of Austin (1962) and Searle (1969). They are able to provide a shift from constative notion to performative notion in the empirical verifiability of signs; that is, the truthfulness of signs to what an expression does when it is uttered.

Speech acts according to Austin (1962) fall into three classes, which are: locutionary, illocutionary and perlocutionary acts. A locutionary act is an act of saying something; that is, the act of producing an utterance. Dada (2004) submits that illocutionary acts are the core of any theory of speech acts. The perculotionary act is the effect or influence on the feelings, thoughts or actions of the listener/hearer unlike locutionary acts. Perlocutionary acts could be inspiring, persuading, consoling, etc. It brings about an effect upon the beliefs, attitudes or behaviours of the addressee. It is in consonance with this that Levinson (1980) describes perlocutionary act as the intended or unintended consequences of the speaker's utterance (Adeyanju, 2009). Searle (1969) improves on Austin's (1962) Speech Act theory by distinguishing between two types of speech acts: Direct and Indirect Speech Acts. Searle (1969) categorizes the illocutionary act into five classes:

1. Assertives: These are statements that describe a state of affairs in the world which could be true or false. They commit a speaker to the truth of the expressed proposition.

2. Directives: These are statements that compel or make another person's action fit the propositional element. It is usually used to give order thereby causing the hearer to take a particular action, request, command or advice.

3. Commisives: These statements commit the speaker to certain future action. It could be in the form of a promise.

4. Expressives: The purpose of expressive statements is to express sincerity of the speech act like excuses and sympathy.

Declaratives: These statements are used to say something and make it so, such as pronouncing someone guilty and declaring a war.

Systemic Functional Linguistics (SFL) was the grammatical model used to carry out the study. This is because SFL enabled the researcher to capture the form and function adequately. Halliday (1970) views language as a means of organizing people and directing their behaviour. In addition, Bloor and Bloor (2004) state that SFL is a 'System of Meanings', which makes it a relevant grammatical model for this research since the 'grammar' of the language and the speaker or writer selects within this system; not in a vacuum but in the context of speech situations (Halliday 1970). The application of the Speech Act theory in the analysis will allow in-depth research into the linguistic features that have been explored by the speaker to inculcate meaning into the formal linguistic properties of the selected speeches.

\section{OBJECTIVE OF THE STUDY}

The research attempts in general terms the analysis of Umaru Musa Yar'Adua's selected political speeches within the theory of Speech Acts. The research is thus meant to identify the speech act features of the selected speeches, to analyse the features in relation to the contexts in which the speeches were presented, and to determine how the identified features project the messages in the speeches.

\section{ReSEARCH MethodOlOGY}

In this work, we chose two speeches of Nigerian President Umaru Musa Yar'Adua. They are Victory Speech and Inaugural Speech. They were the first two speeches delivered by the president in 2007 . We have limited this study to the two speeches in order to be thorough in the analysis of the speeches. The selected speeches were downloaded from the Internet and analysed to show the speech acts performed in the course of delivering the speeches. The linguistic 
approach adopted for the study is pragmatics based on the linguistic framework of Speech Acts theory of Austin (1962) and Searle (1969).

The selected speeches vary in length and number of sentences. We, therefore, extracted specific portions from the speeches. Thus, in each of the speeches, ten sentences comprising the first five and the last five were selected. Twenty sentences in all were selected based on the above criteria .Systemic Functional Linguistics (SFL) as the choice of grammatical model is significant among other grammatical models because of the high premium placed on meanings in the analysis of language and its perception of language as a social activity.

In the course of the analysis, the two speeches selected are labelled A and B. The Victory Speech is A, and Inaugural Speech is labelled B. The numbers of sentences in the extracted portion are ten; therefore, we have A1-10 and B1-10. This was done in order to make the analysis clear and easy to understand. Efforts were made to calculate the percentages of the speech acts types so as to make interpretation of the tables clear and empirical. The calculation of the percentages of the speech acts in a speech is based on the number of sentences and not on the total number of speech acts in each speech. Thus we have;

$\frac{\text { Total number of speech acts }}{\text { Total number of sentences in a speech }} \quad \mathrm{x} \quad \frac{100}{1}$

This served as the basis for our discussion in the research work.

A. The Speech Acts Analysis of Victory Speech (A)

Data A1

Locution:

I am honoured and humbled by the mandate I have received, for the first time in the history of Nigeria we will have an elected President followed by another elected President.

Illocutionary Act:

(a) Direct: assertive (stating)

(b) Indirect: verdictive (assessing)

Expected Perlocutionary Effect: excitement.

Data $A 2$

Locution:

So, many brave Nigerians, including my own brother lived and died to give us this democracy.

Illocutionary Act:

(a) Direct: assertive (stating)

(b) Indirect: declarative (confirming)

Expected Perlocutionary Effect: sympathy.

Data $A 3$

Locution:

I will do all I can to honour their sacrifice.

Illocutionary Act:

(a) Direct: commisive (promising)

(b) Indirect: declarative (confirming)

Expected Perlocutionary Effect: hopefulness.

Data $A 4$

Locution:

The time for politics is over.

Illocutionary Act:

(a) Direct: Assertive (stating)

(b) Indirect: verdictive (assessing)

Expected perlocutionary Effect: excitement

Data A5

Locution:

The time for reconciliation has begun.

Illocutionary Act:

(a) Direct: assertive (stating)

(b) Indirect: directive (assessing)

Expected Perlocutionary Effect: happiness

Data A6

Locution:

There will be no division between Christians and Muslims.

Illocutionary Act:

(a) Direct: directive (appealing)

(b) Indirect: commissive (promising) 
Expected Perlocutionary Effect: encouragement.

Data A7

Locution:

There will be no division between PDP and ANPP and AC and all the rest.

Illocutionary Act:

(a) Direct: directive (appealing)

(b) Indirect: commisive (promising)

Expected Perlocutionary Effect: happiness.

Data $A 8$

Locution:

There will only be Nigeria, one Nation, one People, one Future, one Destiny.

Illocutionary Act:

(a) Direct: assertive (stating)

(b) Indirect: commisive (assurring)

Expected Perlocutionary Effect: hopefulness.

Data A9

Locution:

The ties that bind us together have indeed been frayed but they are strong and so we are.

Illocutionary Act:

(a) Direct: assertive (saying)

(b) Indirect: expressive (savouring the new experience)

Expected Perlocutionary Effect: hopefulness.

Data $A 10$

Locution:

By the grace of God, we will restore those ties, heal the branch and emerge stronger and more united than ever before. Illocutionary Act:

(a) Direct: assertive (saying)

(b) Indirect: commisive (promising)

Expected Perlocutionary Effect: hopefulness.

B. A Speech Act Analysis of Inaugural Speech (B)

Data B1

Locution:

This is a historic day for our nation.

Illocutionary Act:

(a) Direct: assertive (stating)

(b) Indirect: verdictive (assessing)

Expected Perlocutionary Effect: cheerfulness.

Data B2

Locution:

We have at last managed an orderly transition from one elected government to another.

Illocutionary Act:

(a) Direct: assertive (stating)

(b) Indirect: expressive (savouring the country's new experience)

Expected Perlocutionary Effect: excitement.

Data B3

Locution:

We acknowledge that our elections had shortcomings.

Illocutionary Act:

(a) Direct: assertive (stating)

(b) Indirect: verdictive (assessing)

Expected Perlocutionary Effect: appeasement.

Data B4

Locution:

We have well-established legal avenues for redress and I urge anyone aggrieved to pursue them.

Illocutionary Act:

(a) Direct: declarative (confirming)

(b) Indirect: directive (appealing)

Expected Perlocutionary Effect: pacification.

Data B5

Locution: 
I also believe that our experiences represent an opportunity to learn from our mistakes.

Illocutionary Act:

(a) Direct: assertive (stating)

(b) Indirect: expressive (savouring the situation)

Expected Perlocutionary Effect: reconciliatory.

Data B6

Locution:

Let us stop justifying every shortcoming with that unacceptable phrase 'the Nigerian factor' as if to be a Nigerian is to settle for less.

Illocutionary Act:

(a) Direct: directive (appealing)

(b) Indirect: verdictive (assessing)

Expected Perlocutionary Effect: sobriety and reflective.

Data B7

Locution:

Let us recapture the mood of optimism that defined us at the dawn of independence, that legendary spirit that marked our Nigerianness.

Illocutionary Act:

(a) Direct: directive (appealing)

(b) Indirect: verdictive (assessing)

Expected Perlocutionary Effect: inspiring.

Data B8

Locution:

Let us join together, now, to build a society worthy of our children.

Illocutionary Act:

(a) Direct: directive (appealing)

(b) Indirect: verdictive (instructing)

Expected perlocutionary Effect: hopefulness.

Data B9

Locution:

We have the talent, we have the intelligence, and we have the ability.

Illocutionary Act:

(a) Direct: assertive (stating)

(b) Indirect:commisive (assuring)

Expected Perlocutionary Effect: encouraging and inspiring.

Data B10

Locution:

The challenge is great, the goal is clear, the time is now.

Illocutionary Act:

(a) Direct: declarative (confirming)

(b) Indirect: verdictive (assessing)

Expected Perlocutionary Effect: determining and encouraging.

TABLE 1

DATA A (VICTORY SPEECH)

\begin{tabular}{|l|l|l|}
\hline SPEECH ACTS(DIRECT AND INDIRECT) & FREQUENCIES & PERCENTAGES \\
\hline Assertive & 7 & $70 \%$ \\
\hline Directive & 3 & $30 \%$ \\
\hline Expressive & 1 & $10 \%$ \\
\hline Verdictive & 2 & $20 \%$ \\
\hline Commisive & 5 & $50 \%$ \\
\hline Declarative TOTAL NO OF ACTS & 2 & $20 \%$ \\
\hline \multicolumn{2}{|c|}{20} \\
\hline
\end{tabular}

TABLE 2

DATA B (INAUGURAL SPEECH)

\begin{tabular}{|l|l|l|}
\hline SPEECH ACTS(DIRECT AND INDIRECT) & FREQUENCIES & PERCENTAGES \\
\hline Assertive & 5 & $50 \%$ \\
\hline Directive & 4 & $40 \%$ \\
\hline Expressive & 2 & $20 \%$ \\
\hline Verdictive & 6 & $60 \%$ \\
\hline Commisive & 1 & $10 \%$ \\
\hline Declarative & 2 & $20 \%$ \\
\hline \multicolumn{2}{|c|}{20} \\
\hline
\end{tabular}


TABLE 3

SUMMARY OF THE TABLES A - B (ORFPS)

\begin{tabular}{|l|l|l|}
\hline SPEECH ACTS (DIRECT AND INDIRECT) & FREQUENCIES & PERCENTAGES \\
\hline Assertive & 12 & $60 \%$ \\
\hline Directive & 7 & $35 \%$ \\
\hline Expressive & 3 & $15 \%$ \\
\hline Verdictive & 8 & $40 \%$ \\
\hline Commisive & 6 & $30 \%$ \\
\hline Declarative & 4 & $20 \%$ \\
\hline \multicolumn{2}{|c|}{40} \\
\hline
\end{tabular}

\section{INTERPRETATION OF THE ANALYSIS ON TABLES}

Language is a powerful weapon in getting to the political thoughts and ideologies of politicians; hence the language use of Yar'Adua is studied through the two selected speeches in order to get to his thoughts. The Speech Act theory was applied to the study of the speeches and we discovered that the five categories of Searle's (1969) speech acts manifested with verdictives category from Austin (1962). It is pertinent to state that the speech acts could be intended or unintended, as the speaker is often unaware of some speech acts tactics especially the indirect illocutionary acts.

It was discovered from the Victory speech that the President had used mainly sentences that were assertive as they have a total percentage of 70\%, while 50\% of the sentences in Victory speech were commisive and 30\% were directive, while expressive was $10 \%$, verdictive (20\%) and declarative (20\%). The President had used mainly assertives, commisives and verdictives. In effect, upon the announcement of Umaru Musa Yar'Adua at the polls, it was apt for him to commence the use of verdictives and directives, which is typical of people in power or someone occupying a position of authority just to give instructions and orders that will guide his administration.

The assertives in the Inaugural speech were $50 \%$, which is to say that Yar'Adua used language to state, maintain, inform, and promise his subjects. The speech acts in the Inaugural speech were mainly verdictives, that is, $60 \%$ of the sentences are verdictives, and $40 \%$ of the sentences are directives, while 50\% were assertives. With this, the President demonstrated his power as the Commander-In-Chief of the Armed Forces of Nigeria through his heavy reliance on the use of speech acts that are assertives and verdictives by asserting his authority.

From the Tables, we realized that each of the sentences analysed performed both direct illocutionary and indirect acts. This showed that the President did more than saying or stating, in the process of making statements, various other speech acts were performed. The fact that all the sentences have both direct and indirect speech acts brought the total number of the illocutionary acts in the sixty sentences to one hundred and twenty. The indirect acts were mainly in the categories of directives, verdictives, commisives, expressives and declaratives.

In a global macro-speech act sense, the totality of the speeches selected and analysed in our data displayed efforts made by President Yar'Adua to make the public accept his government and co-operate with him. He was not forceful in his speeches; the Inaugural Speech manifested high frequency of verdictives with $60 \%$ of the sentences. This was because at the initial stage, he was trying to lay claim to his power and authority as the newly elected President and he demonstrated this in the two speeches, hence the wide use of these acts in the speeches.

It was discovered from the overall relative frequency percentages (ORFPs) tables that the President had used mainly sentences that were assertive with $60 \%$ of the total sentences. This is far higher than the ORFPs for directive acts which had a subtotal of 35\%. This was followed by commisive acts with 30\%, and the verdictives with $40 \%$ on the ORFPs table while declaratives had 20\% and expressives had 15\%. It was then apparent from the ORFPs that the President used these acts in this manner to show a perculiar style of civilian politician by being assertive in most of the sentences in his speeches.

Adeyanju $(2009,186)$ rightly opines that the major preoccupation of Nigerian political leaders is the quest for acceptance and cooperation which is borne out of the idea that a political leader cannot succeed if he does not enjoy the acceptance and cooperation of the people. Noteworthy is the fact that President Umaru Yar'Adua speeches are distinct from Military leaders' speeches. Military leaders make use of sentences that are highly verdictive and directive. We observed that the sentences that were verdictives in President Yar'Adua speeches were basically meant for assessing, and directives were mainly for appealing, and not commanding which is usually the case with the Military Political leaders' speeches.

\section{CONCLUSION}

In this study, we discovered that the identification of speech acts types in speeches go a long way in ascribing meanings to such speeches. In other words, the speech acts bring to the fore meaning in speeches. As observed, in the process or act of saying something; other speech acts are performed. Therefore, there is no sentence that does not contain one speech act or the other. The speech acts in a work portray the personality of the speaker. President Umaru Yar'Adua was a political leader. President Umaru Yar'Adua speeches are direct and clear with speech acts that are easily identified. 
We discovered from the analysis of the President Umaru Musa Yar'Adua Victory and Inaugural speeches that democratic government places premium on the interest of the people. There was no record of verdictive speech acts that were used by the president in the commanding sense. The Speech Act theory as a framework in the analysis of President Yar'Adua speeches enables us to explore the language use of political leaders. This fact is confirmed by the speech acts that are manifested through our analysis. Through the application of Speech Act theory to study President Umaru Yar'Adua's speeches, the readers are better equipped in understanding the application of Speech Act theory to political speeches.

\section{REFERENCES}

[1] Agbogun, A.A. (2011).'A Linguistic- Stylistic Analysis of Post- Appeal Court Victory Speeches of Selected Governors of Nigeria' An Unpublished M.A. Thesis of Department of English, Obafemi Awolowo University, Ile-Ife.

[2] Adetunji, A. (2006). 'Inclusion and Exclusion in Political Discourse: Deixis in Olusegun Obasanjo's Speeches'. Journal of Language and Linguistics 5(2): 177-191.

[3] Adeyanju D. (2009). 'Pragmatic Features of Political Speeches in English by Some Prominent Nigerian Leaders'. Journal of Political Discourse Analysis. Vol. 2(2). U.S.A.: Nova Science Publisher.

[4] Austin, J.L. (1962). How to Do Things with Words. Oxford: Oxford University Press.

[5] Awonuga, C.O. (1988). 'Political Rhetoric: Awolowo's Use of Language'. Odu: A Journal of West African Studies 34: 150-196.

[6] Awonuga, C.O. (2005). 'A Stylistic Study of Sustenance of Democracy by Olusegun Obasanjo'. Journal of Social Science 11(2): 111-119.

[7] Ayeomoni, M. O. (2005a). 'A Linguistic-Stylistic Analysis of Some Political Speeches of Past Nigerian Military Rulers' in Papers in English and Linguistics (PEL) Vol. 6, Ile-Ife: The Linguistic Association. 1-13

[8] Ayeomoni, M. O. (2005b). 'Grapho-Syntactic Analysis of Selected Political Speeches of Some Nigerian Military Heads of State', in Awka Journal of Linguistics and Languages. Edited by Philip, N. Anagbogu. No. 1, Department of Linguistics, Nnamdi Azikiwe University Awka. 1-9.

[9] Ayoola, K. (2005). 'Interpreting Nigeria's Political Discourse: A Study of President Olusegun Obasanjo's July 26, 2005 Address to Nigeria's National Assembly'. Papers in English Linguistic (PEL) Vol. 6: 1-13. Ile-Ife: The Linguistics Association

[10] Beard, A. (2000). The Language of Politics. London: Routledge.

[11] Bloor, T., and M. Bloor (2004). The Functional Analysis of English: A Hallidayan Approach. London: Arnold.

[12] Dada, S.A. (2004). 'Introduction to Pragmatics' In T. Bamisaye (ed.) An Integrated Study in Language and Society. Lagos: Majab Publishers, 141-166.

[13] Halliday, M.A.K. (1970). 'Language Structure and Language Function'. In John Lyons (ed.) New Horizons in Linguistics. U.S.A.: Penguin Books. 142-165.

[14] Opeibi, B.O. (2009). Discourse, Politics and the 1993 Presidential Election Campaigns in Nigeria .Lagos: Nouvelle Communications Limited.

[15] Searle, J.R. (1969). Speech Acts. Cambridge: Cambridge University Press.

[16] Taiwo, R. (2009). 'Legitimization and Coercion in Political Discourse: A Case Study of Olusegun Obasanjo Address to the PDP Elders and Stakeholders Forum'. Journal of Political Discourse Analysis. Vol. 2(2).191-205.

[17] Thomas, J. (1995). Meaning in Interaction: An Introduction to Pragmatics. New York: Longman.

Omoniyi Moses Ayeomoni is a native of Okitipupa, Ondo State of Nigeria, born in 1960. He holds a Ph.D degree in English Language from University of Ibadan, Ibadan, Nigeria in 1997.

Currently, he is a senior lecturer at the department of English, Obafemi Awolowo University, Ile-Ife, Nigeria. He has published widely in both local and International Journals.

Dr. Ayeomoni is a member of West African Linguistics Society.

Olajoke Susan Akinkuolere is a native of Ilutitun in Okitipupa Local Government of Ondo State, Nigeria. She is happily married to Mr. Akinkuolere, a frontline Politician in Nigeria.

She has a master degree in English Language from Obafemi Awolowo University, Ile- Ife, Osun State Nigeria in 2011. She is currently a lecturer in the Department of General Studies, Rufus Giwa Polytechnic Owo, Ondo State, Nigeria.

Mrs. Akinkuolere is the Secretary of Academic Staff Union of Nigerian Polytechnics (ASUP) Owo branch, Ondo State. 